\title{
Flow cytometric analysis of FSHR, BMRR1B, LHR and apoptosis in granulosa cells and ovulation rate in merino sheep
}

\author{
Sheena L P Regan, James R McFarlane ${ }^{1}$, Tim $\mathrm{O}^{\prime}$ Shea ${ }^{1}$, Nicholas Andronicos ${ }^{1}$, Frank Arfuso, \\ Arun Dharmarajan and Ghanim Almahbobi \\ School of Biomedical Sciences, Curtin Health Innovation Research Institute, Curtin University, GPO Box U1987, \\ Perth, Western Australia 6845, Australia and ${ }^{1}$ Centre of Bioactive Discovery in Health and Ageing, \\ University of New England, Armidale, New South Wales, Australia
}

Correspondence should be addressed to S L P Regan; Email: sheenaregan@aapt.net.au

\begin{abstract}
The aim of the present study was to determine the direct cause of the mutation-induced, increased ovulation rate in Booroola Merino (BB) sheep. Granulosa cells were removed from antral follicles before ovulation and post-ovulation from BB $(n=5)$ and WT $(n=12)$ Merino ewes. Direct immunofluorescence measurement of mature cell surface receptors using flow cytometry demonstrated a significant up-regulation of FSH receptor (FSHR), transforming growth factor beta type 1, bone morphogenetic protein receptor (BMPR1B), and LH receptor (LHR) in BB sheep. The increased density of FSHR and LHR provide novel evidence of a mechanism for increasing the number of follicles that are recruited during dominant follicle selection. The compounding increase in receptors with increasing follicle size maintained the multiple follicles and reduced the apoptosis, which contributed to a high ovulation rate in BB sheep. In addition, we report a mutation-independent mechanism of down-regulation to reduce receptor density of the leading dominant follicle in sheep. The suppression of receptor density coincides with the cessation of mitogenic growth and steroidogenic differentiation as part of the luteinization of the follicle. The BB mutation-induced attenuation of BMPR1B signaling led to an increased density of the FSHR and LHR and a concurrent reduction in apoptosis to increase the ovulation rate. The role of BMPs in receptor modulation is implicated in the development of multiple ovulations.

Reproduction (2015) $\mathbf{1 5 0} 151-163$
\end{abstract}

\section{Introduction}

Ovarian follicular maturation relies on the gonadotropins follicle-stimulating hormone (FSH) and luteinizing hormone (LH) to regulate the cyclic recruitment of dominant follicle selection, which governs the ovulation rate in animals and in humans (McNatty \& Henderson 1987, Ginther et al. 2005, Mihm \& Evans 2008). It is commonly believed that intra-ovarian growth factors such as the transforming growth factor beta (TGF $\beta$ ) family of bone morphogenetic proteins (BMPs) influences the steroidogenic activity of $\mathrm{LH}$ and $\mathrm{FSH}$ directly, and it does so indirectly downstream of the receptor (Otsuka 2010). The cellular mechanism responsible for the selection of the dominant follicle cohort remains elusive (Westergaard et al. 1986, Andersen et al. 1993, Ginther et al. 2005, Knight \& Glister 2006, Mihm \& Evans 2008).

Previous studies have delineated the initial role of FSH as a stimulatory growth factor for the proliferation of follicular cells and the oocyte, which culminates in a mid-follicular peak of FSH (Thomas et al. 2005, Mihm \& Evans 2008). A sharp decline in FSH causes the follicles that are still dependent on FSH to succumb to atresia, which results in a dominant follicle cohort. The follicles survive because they are mature enough to be FSHindependent, or they become more responsive to $\mathrm{FSH}$ because of the greater concentration of $\mathrm{FSH}$ receptors (FSHRs). The manipulation of FSH through the use of exogenous $\mathrm{FSH}$ forms the basis of artificial reproduction treatment (ART) in humans. By artificially increasing FSH in ART, the FSH concentration remains high and thereby supports the smaller FSH-dependent follicles; this results in multiple pre-ovulatory follicles for collection and fertilization. Treatment with high doses of FSH is a systemic whole-body approach to artificial stimulation, but it has associated risks, such as hyper-stimulation, hormonal disruption, and discomfort. An in-depth understanding of follicular regulation might lead to improved targeted approaches to infertility treatment.

We have known for some time that the Booroola Merino (BB) genotype, with its naturally occurring point 
Table 1 Number of individual follicles analyzed before ovulation.

\begin{tabular}{|c|c|c|c|c|c|c|c|}
\hline Genotype & $\begin{array}{c}\text { Sheep before } \\
\text { ovulation }\end{array}$ & Follicle & $\begin{array}{l}\text { Dominant } \\
\text { follicles }\end{array}$ & $\begin{array}{c}\text { Small } \\
(1.0-2.1 \mathrm{~mm})\end{array}$ & $\begin{array}{c}\text { Medium } \\
(2.2-2.9 \mathrm{~mm})\end{array}$ & $\begin{array}{c}\text { Large } \\
(3.0-4.5 \mathrm{~mm})\end{array}$ & $\begin{array}{c}\text { Extra large } \\
(4.6-7.0 \mathrm{~mm})\end{array}$ \\
\hline WT & 8 & 64 & 8 & 25 & 19 & 14 & 6 \\
\hline BB & 3 & 20 & 3 & 9 & 5 & 6 & 0 \\
\hline
\end{tabular}

mutation of the TGF $\beta$ superfamily of cytokines type 1 receptor, BMPR1B, has an increased ovulation rate (Mulsant et al. 2001). The cellular mechanism responsible for this increase, however, has not been revealed (Mulsant et al. 2001, Souza et al. 2001, Wilson et al. 2001, Campbell et al. 2003, Crawford et al. 2011). Evidence from our previous findings in BB sheep has shown that the attenuation of BMP signaling produces elevated FSH levels, and the initial number of primordial follicles are reduced; yet the rate of recruitment of primary follicles is substantially lower and results in a greater retention of the ovarian reserve in the mature ewe (Xia et al. 2003, Ruoss et al. 2009). Given that FSHRs are not expressed in primordial follicles, it is unlikely that FSH plays a role in this initial recruitment (Ruoss et al. 2009). The BMP ligands have been implicated in the stimulatory regulation of primordial to primary follicle recruitment, particularly BMP4 and BMP7, which provides some explanation for the reduction reported (Ruoss et al. 2009).

The mutation in BMPR1B in BB sheep provides a unique opportunity for studying the role of BMPs in ovarian function, including follicle development, growth, ovulation, and the clinical treatment of subfertility in humans. The response of both the ovary and the pituitary to gonadotropic stimulation appears to be responsible for the increased ovulation rate of the $\mathrm{BB}$ mutation (Fry et al. 1988, Hudson et al. 1999, Campbell et al. 2003, Hampton et al. 2004). Our previous results have led us to initiate further research to delineate the direct cellular mechanism responsible for the increased response of the ovary to gonadotropins, which leads to an increased ovulation rate, and to provide further insight into the interplay between the intra-ovarian BMP ligands and the regulatory $\mathrm{FSH}$ and $\mathrm{LH}$ in terminal end folliculogenesis.

We hypothesized that if there is reduced initial primary follicle recruitment, greater survival of antral follicles would be required to deliver a greater ovulation rate. Direct measurement by flow cytometry of the protein expression of $\mathrm{FSH}, \mathrm{LH}$, and BMP mature membrane-bound receptors on granulosa cells as well as apoptosis and necrosis was undertaken to fully delineate the natural point mutation effect of the BB responsible for the increased ovulation rate. We therefore hypothesized that the attenuation of the BMP signal would provide a more direct and accurate intra-ovarian method for increasing the ovulation rate in ART.

\section{Materials and methods}

\section{Animals, ovaries, and follicles}

A total of 17 Merino sheep with an average age of 4 years 9 months \pm 2 months were used (Tables 1 and 2). The animals were housed in open paddocks at the University of New England, NSW, Australia, in accordance with the NH \& MRC Code of Practice for the Care and Use of Animals for Experimental Purposes. All of the experiments were approved by the University of New England Animal Ethics Committee. Five ewes were genetically confirmed to be homozygous Australian BB strain; the flock average ovulation rate was four to six during peak breeding season (Cummins et al. 1983), and the average ovulation rate was three, based on the corpus luteum (CL) formation in two BB sheep at the time of slaughtering, because of mistimed ovulation. Subsequently, the remaining follicles after ovulation were classified as luteinized (Table 2). The $\mathrm{CL}$ formed in the post-ovulation groups were included in the total number of follicles recruited per genotype, and they were added to the largest follicle size for that genotype (Table 3). The estrus cycles of these animals were synchronized using flugesterone acetate sponges (Bioniche Animal Health, Armidale, NSW, Australia). The sponges were removed from the animals 14 days after insertion, and the animals received an i.m. injection of $1000 \mathrm{IU}$ of pregnant mare's serum gonadotropin. The animals were euthanized $\sim 36 \mathrm{~h}$ after sponge removal, and the ovaries were collected (Evans 2003).

\section{Collection of granulosa cells}

Follicle size was established by preparing standard blank volumes in $5 \mu \mathrm{l}$ increments from 5 to $160 \mu \mathrm{l}$; these were placed in identical PCR tubes and were visually compared to the follicular fluid aspirated from each follicle based on previously published techniques (Jakimiuk et al. 2002, Andersen et al. 2010). The blank values were used as a reference to estimate the diameter of the follicle, and they were cross-referenced

Table 2 Number of follicles analyzed post-ovulation.

\begin{tabular}{|c|c|c|c|c|c|c|c|}
\hline Genotype & $\begin{array}{c}\text { Sheep post- } \\
\text { ovulation }\end{array}$ & $\begin{array}{c}\text { Luteinized } \\
\text { follicles }\end{array}$ & CL per sheep & $\begin{array}{c}\text { Small } \\
(1.0-2.1 \mathrm{~mm})\end{array}$ & $\begin{array}{c}\text { Medium } \\
(2.2-2.9 \mathrm{~mm})\end{array}$ & $\begin{array}{c}\text { Large } \\
(3.0-4.5 \mathrm{~mm})\end{array}$ & $\begin{array}{c}\text { Extra large } \\
(4.6-7.0 \mathrm{~mm})\end{array}$ \\
\hline WT & 4 & 35 & 1.5 & 13 & 14 & 8 & 0 \\
\hline $\mathrm{BB}$ & 2 & 10 & 3 & 7 & 2 & 1 & 0 \\
\hline
\end{tabular}

$\mathrm{CL}$, corpus luteum. 
Table 3 Recruitment and loss of follicles during folliculogenesis in WT and BB merino sheep.

\begin{tabular}{|c|c|c|c|c|c|c|c|c|c|c|c|c|}
\hline \multirow[b]{2}{*}{ Genotype } & \multirow[b]{2}{*}{$\begin{array}{r}\text { Total } \\
\text { sheep }\end{array}$} & \multirow[b]{2}{*}{$\begin{array}{c}\text { Total } \\
\text { follicles }^{\mathrm{a}}\end{array}$} & \multirow[b]{2}{*}{$\begin{array}{c}\text { Total per } \\
\text { sheep }\end{array}$} & \multicolumn{3}{|c|}{$\begin{array}{c}\text { Small } \\
(1.0-2.1 \mathrm{~mm})\end{array}$} & \multicolumn{2}{|c|}{$\begin{array}{c}\text { Medium } \\
(2.2-2.9 \mathrm{~mm})\end{array}$} & \multicolumn{2}{|c|}{$\begin{array}{c}\text { Large } \\
(3.0-4.5 \mathrm{~mm})\end{array}$} & \multicolumn{2}{|c|}{$\begin{array}{c}\text { Extra large } \\
(4.6-7.0 \mathrm{~mm})\end{array}$} \\
\hline & & & & $\begin{array}{c}\text { Small follicles } \\
\text { pooled }\end{array}$ & $\begin{array}{c}\text { Total } \\
\text { collected }\end{array}$ & $\begin{array}{c}\text { Total } \\
(\%)\end{array}$ & $\begin{array}{c}\text { Total } \\
\text { collected }\end{array}$ & $\begin{array}{l}\text { Total } \\
(\%)\end{array}$ & $\begin{array}{c}\text { Total } \\
\text { collected }\end{array}$ & $\begin{array}{l}\text { Total } \\
(\%)\end{array}$ & $\begin{array}{c}\text { Total } \\
\text { collected }\end{array}$ & $\begin{array}{l}\text { Total } \\
(\%)\end{array}$ \\
\hline WT & 12 & 150 & 12.5 & 42 & 80 & 53 & 33 & 22 & 23 & 16 & $14^{\mathrm{a}}$ & 9.3 \\
\hline $\mathrm{BB}$ & 5 & 49 & 9.8 & 12 & 28 & 57 & 7 & 14 & $14^{\mathrm{a}}$ & $28.6^{*}$ & 0 & 0 \\
\hline
\end{tabular}

Significantly greater number of ovulating follicles, ${ }^{*} P<0.011$.

ancluding corpus luteum.

with a direct measurement of the diameter of the follicle using a fine ruler gauge before aspiration. The follicular fluid was aspirated from all of the visible follicles using a 25-gauge needle, and it was then placed into PCR tubes. All of the visible surface follicles were harvested, and very small follicles $(1-1.8 \mathrm{~mm})$ of the same size were pooled in groups of three or four, whereas all of the medium, large, and extra-large follicles were analyzed individually (Tables 1 and 2).

On a follicle-by-follicle basis, an in situ incision was made at the exposed surface of the follicle with a scalpel; granulosa cells were gently scraped with the blunt side of the scalpel, flushed repeatedly with PBS, and resuspended in PBS. The sheets of granulosa cells were dispersed by mechanical pipetting and centrifuged at an optimized lower speed of $300 \boldsymbol{g}$ for $5 \mathrm{~min}$ to protect the cells from method-induced apoptosis and to yield an uncontaminated population of granulosa cells. Collection without excision of the whole follicle prevents contamination with the theca or stroma cells and limits the amount of contamination with blood cells (Fig. 1).

Based on the hierarchical down-regulation previously reported, the sheep follicles were divided into subordinate, dominant, and luteinized post-ovulation follicles (Driancourt et al. 1985, Evans 2003). The largest follicle collected from each sheep before ovulation was classified as the dominant follicle, and the remaining follicles were classified as subordinated follicles (Gasperin et al. 2014).

\section{Receptors}

Aliquots of suspended granulosa cells $\left(1 \times 10^{6}\right.$ cells in $\left.100 \mu \mathrm{l}\right)$ were immunolabeled using a double-indirect method as previously described (Cai et al. 2007, Gao et al. 2007, Abir et al. 2008). The cells were incubated separately with an optimized concentration of $4 \mu \mathrm{g} / \mathrm{ml}$ affinity purified polyclonal antibody to BMPR1B, FSHR, or LH receptor (LHR) for $25 \mathrm{~min}$ at $5{ }^{\circ} \mathrm{C}$ (Millennium Science, Surrey Hills, VIC, Australia). Previously, we established the specificity in sheep by immunofluorescence detection and 3D image analysis (Al-Samerria \& Almahbobi 2014). The antibodies were polyclonal goat anti-BMPR1B (sc-5679), goat anti-FSHR (sc-7798), and goat anti-LHR (sc-26341) (all from Santa Cruz Biotechnology), anti-goat second antibody conjugated with Alexa 488 (Al-Samerria \& Almahbobi 2014). In addition, the antibodies have been previously reported in human studies (Haÿ et al. 2004, Cai et al. 2007, Gao et al. 2007, Pidoux et al. 2007, Abir et al. 2008) and using flow cytometry (Gao et al. 2007). Immunolocalization of LHR in human placental trophoblasts demonstrated positive strong staining with human chorionic gonadotropin, and no staining was observed in nonspecific isotypic negative controls (Pidoux et al. 2007). In the same study, RT-PCR products were sequenced and confirmed LHR fragments (Pidoux et al. 2007). BMPRIB, FSHR, and LHR were raised against a sequence between amino acids of human origin, with 88,80 , and $93 \%$ sequence identity to the sheep protein respectively. Donkey anti-goat IgG conjugated with Alexa 488 (Life Technologies Australia), with an excitation wave length of $495 \mathrm{~nm}$ and an emission wave length of $519 \mathrm{~nm}$, was applied at an optimized concentration of $4 \mu \mathrm{g} / \mathrm{ml}$ for $25 \mathrm{~min}$ and was repeat washed in PBS.

Blocking peptides for BMPR1B and FSHR indicated nonspecific binding applied to human granulosa cells (sc-5679P; Millennium Science), as previously published (Haÿ et al. 2004, Cai et al. 2007, Gao et al. 2007, Pidoux et al. 2007, Abir et al. 2008).
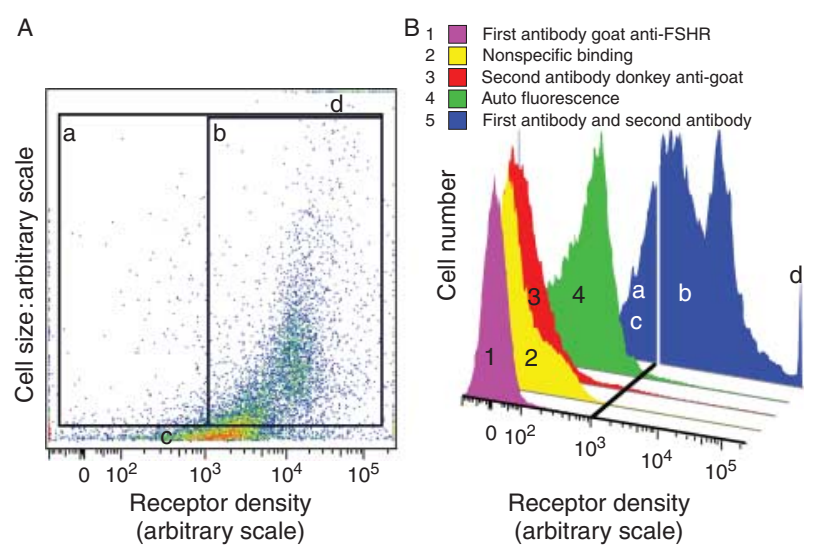

Figure 1 Validation of the method of subtraction gating; removal of autofluorescence and nonspecific binding. (A) Flow cytometric dot plot, with forward scatter representing size of cell and showing positively identified granulosa cells. (A, a) Subtracted (gated box) cells resulting from either autofluorescence or nonspecific binding; $(A, b)$ the average number of granulosa cells 4971; $(A, C)$ gating to exclude debris; and $(A, d)$ doublet cells. (B) Histogram of cell number and fluorescent intensity of the corresponding a, b, c, and d population in Figure A. Where $b$ (blue) represents the mean granulosal receptor density; gated between $10^{3}$ and $10^{5}$, to exclude a, c and d combined. Nonspecific binding $\left(2=\right.$ yellow); auto-fluorescence $(4=$ green $) ; 1^{\text {st }}$ antibody Goat Anti FSHR ( $1=$ pink); and $2^{\text {nd }}$ Antibody Donkey Anti Goat $(3=$ red $)$ combined (a) and gated at $10^{3}$. Additional gating of debris, gated at $10^{3}$ (c) and doublet cells, gated at $>10^{5}$ (d). Scale arbitrary units. 


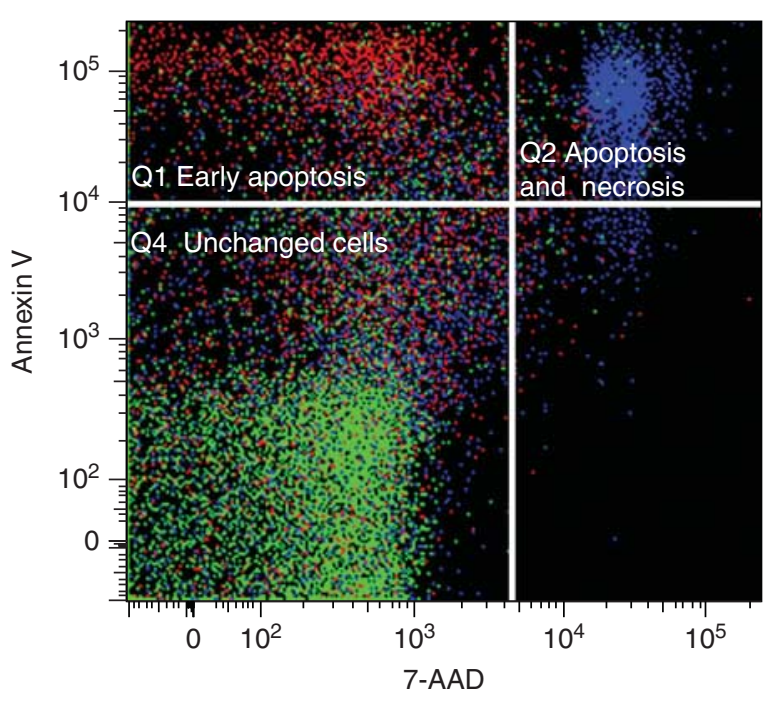

Figure 2 Apoptosis and necrosis quantification by immunolabeling and flow cytometry. Flow cytometric analysis of granulosa cells stained with fluorescent antibodies for annexin $\mathrm{V}$ and 7-AAD to depict the viability of the cells. Quadrant 1 (Q1): positive for annexin $V$ and negative for 7-AAD, which indicates only early apoptosis with an intact cell membrane. Q2: positive for annexin $\mathrm{V}$ and 7-AAD, which indicates apoptosis and necrosis. Q4: negative for annexin $\mathrm{V}$ and 7-AAD, which indicates an intact cell membrane with no externalization of the phospholipid phosphatidylserine and no apoptosis and necrosis. The frequency of granulosa cell apoptosis or unspecified cell death was graphed (Q2).

\section{Flow cytometry}

The samples were prepared as a single-cell suspension, stained for flow cytometric analysis, and immediately processed using an LSRII flow cytometer (BD, North Ryde, NSW, Australia). The data were analyzed using Flowjo Software (Tree Star, Inc., Ashland, OR, USA). Selective gating of the whole sample in order to identify a pure granulosa cell population with an average of 4000 granulosa was achieved by graphing forward scatter (increasing size) on the $y$-axis and fluorescence intensity (Alexa 488) on the $x$-axis. A large gating box excluded small cellular fragments along the $x$-axis (letter ' $C$ ') and cell doublets on the top border (letter ' $d$ ') (Fig. 1A and B). The resulting population was graphed on to a histogram for the number of granulosa cells and the density of receptors (letters ' $a$ and b' in Fig. 1A and B). Negative control samples were assessed either as unstained samples or by the substitution of primary antibody with pre-immune goat IgG (Millennium Science) at the same concentration as the primary antibody. The fluorescence intensity threshold gate at $10^{3}$ (solid line) excludes emitted autofluorescence number 4 and nonspecific binding numbers 1, 3, and 4 (letter ' $a$ ' combined, Fig. 1B). The resulting population contained a uniform granulosa cell population that revealed positive staining for the FSHR, which is unique to granulosa cells in the follicle (letter ' $b$ ' in Fig. 1A and B; Gao et al. 2007, Stilley et al. 2014). The predetermined gates were established and set for all of the samples. The positive quantitative signal (mean fluorescent intensity (MFI)) for the average granulosa cell receptor density (letter ' $b$ ') is indicated in Fig. 1B.

\section{Apoptosis}

For the detection of apoptosis and necrosis, the assessment was applied on the same aliquots that were used for the immunolabeling of FSHR with a double-direct method, as previously described (Riccardi \& Nicoletti 2006, Demchenko 2013). Briefly, after washing the cells with the prescribed annexin $\mathrm{V}$ phospholipid-binding, calcium-dependent buffer, a $\mathrm{MAB}$ to annexin $\mathrm{V}$ conjugated to the fluorochrome phycoerythrin (PE) and the nucleic acid dye 7-amino-actinomycin (7-AAD) (BD Biosciences, Perth, WA, Australia) were added for a final concentration of $5 \mu \mathrm{l} / 1 \times 10^{6}$ cells. The solution was incubated in the dark for $15 \mathrm{~min}$ at room temperature as previously reported (Schmid et al. 1992, Vermes et al. 1995) and validated against propidium iodine. A combination of unstained cells, cells stained with only PE annexin V, and cells only stained with 7-AAD were used as positive and negative controls and to establish gating limits.

PE annexin $V$ and 7-AAD were graphed into quadrants (Fig. 2). Quadrant 1 (Q1) events were positive for PE annexin $V$ and represent a very early stage of apoptotic granulosa cells. Q2 was positive for both PE annexin $\mathrm{V}$ and 7-AAD and therefore represents a later stage of apoptosis and necrosis. Cell membrane integrity breakdown in Q2 allowed 7-AAD to penetrate, whereas in Q4, unchanged cells showed no externalization of the phospholipid, were receptive to the annexin stain, and were negative to 7-AAD penetration (Fig. 2). All of the graphs for apoptosis and necrosis were based on Q2, which indicates a combination of apoptosis and necrosis. Q1 was not reliable because the positive stain for early apoptosis may have been induced during cell preparation and therefore would not be a true indication of cell health status (Amsterdam et al. 2003, Demchenko 2013).

\section{Fluorescent microscopy}

Resuspended $10 \mu \mathrm{l}$ aliquots of FSHR, BMPR1B, and LHR immunolabeled live granulosa cells were placed on slides and visualized in order to characterize and confirm receptor expression (Fig. 3) using an Olympus DP 70 camera fitted to an Olympus BX-51 upright fluorescence microscope with a $40 \times$ UPlan N 0.4 NA objective (Olympus Imaging Australia). Pelleted aliquots of PE annexin $\mathrm{V}$ immunolabeled samples were similarly visualized for apoptosis. Fluorescence microscopy revealed a positive staining of the cell membrane-bound FSHR, BMPR1B, and LHR (Fig. 3E, F and G) as an intermittent, bright, ring-like pattern around the cells. Positive staining for early apoptosis was revealed by the labeling of annexin V (Fig. $3 \mathrm{H}$ ). All of the control samples showed negative staining (data not shown).

\section{Statistical analysis}

MFI was obtained using an average of 4000 granulosa cells/follicle for the direct measurement of mature functional receptor protein density. All of the data were subject to statistical verification by one-way ANOVA with an uncorrected Fisher's least significant difference (LSD) for follicular size and genotype using GraphPad Prism 6 (GraphPad Software, Inc., San Diego, CA, USA). Values in the graphs are presented as 


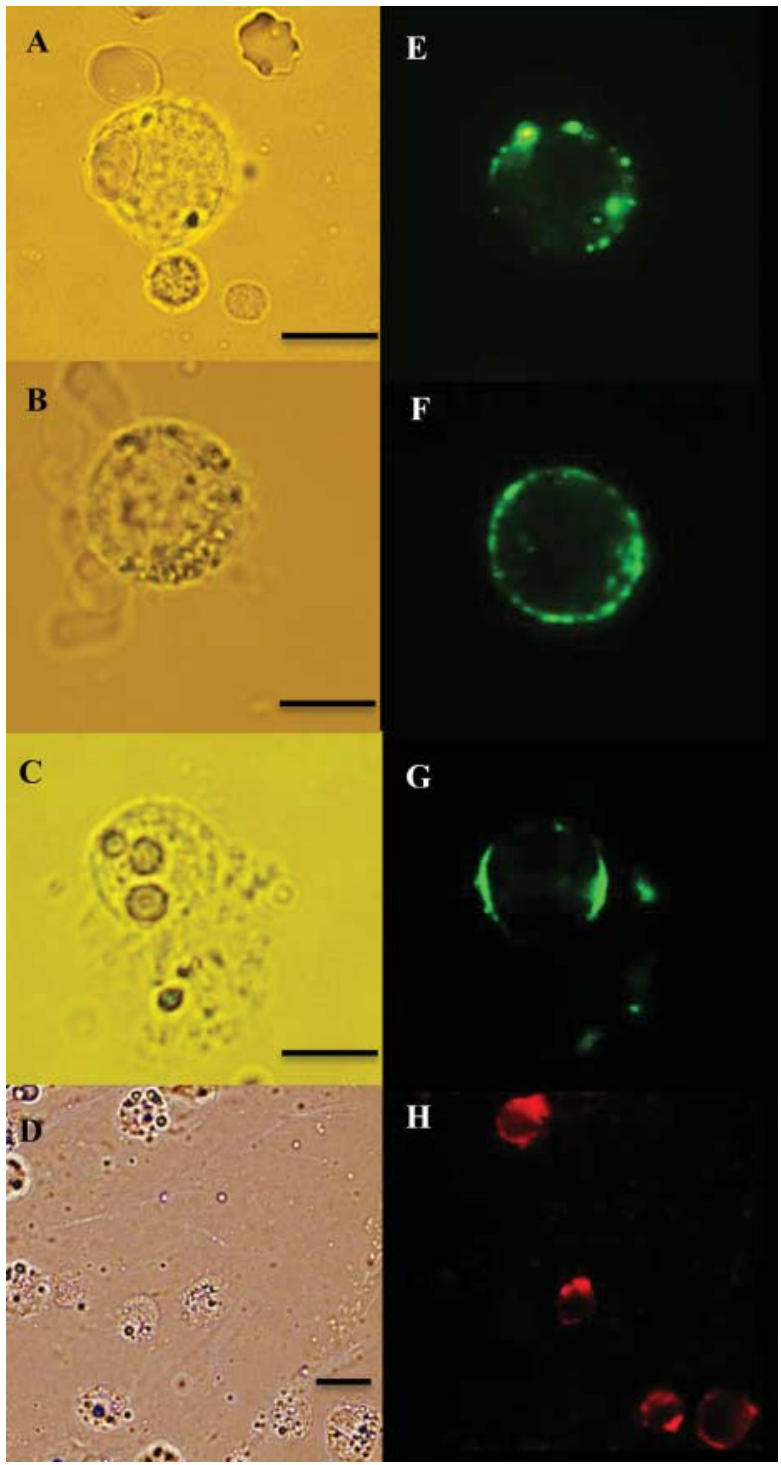

Figure 3 Localization of granulosa cell membrane surface receptors. Characterization of the presence of the receptors at the cell surface and early apoptosis. (A) Living un-luteinized granulosa cell (center), red blood cell (top), and white blood cell (bottom). (E) Polyclonal goat antibody FSHR anti-goat donkey IgG conjugated with Alexa 488 demonstrating specific fluorescence for cell membrane-expressed FSHR. (B and F) A granulosa cell labeled with anti-BMPR1B. (C and G) Labeled with anti-LHR. All showing cellular membrane receptor expression viewed under a fluorescence microscope and light microscope; original magnification. (D and $\mathrm{H}$ ) Granulosa cells labeled with annexin $\mathrm{V}$ conjugated to PE showing cellular membrane phospholipid externalization, which is indicative of early apoptosis. Viewed under a fluorescence microscope; original magnification. Scale bar $=7.5 \mu \mathrm{m}$.

means \pm S.E.M., and differences were considered significant if $* P<0.05, * * P<0.01,{ }^{* * *} P<0.005$, and $* * * * P<0.001$. The letter ' $a$ ' signifies a statistical difference from the matching letter, and an attached asterisk ( $\left.a^{*}\right)$ indicates the significance level for the size follicle. The results from an analysis of a contingency table by a two-tailed Fisher's exact test are shown in Table 3 and Fig. 4.

\section{Results}

The largest follicle in BB ovaries was $4.5 \mathrm{~mm}$, whereas the largest follicle in the WT animals was $7 \mathrm{~mm}$ (Table 3). The percentage of small follicles, including the pooled follicles, was similar between the genotypes (53\% WT and $57 \%$ BB). The medium WT follicles collected contributed to $22 \%$ of the adjusted total, whereas, the medium BB follicles were significantly less, at 14\%. The large follicle numbers were reversed, with BB sheep having significantly more large ovulatory follicles as compared to the WT extra-large ovulatory follicles, 28.6 and $9.3 \%$ respectively $(P<0.011$, Table 3$)$. The absolute relative frequency derived from the total number of follicles collected was compared to the number of ovulatory-size follicles (Fig. 4). The BB sheep did not produce any extra-large follicles, and the CL formed was included in the largest follicle group for the genotype.

\section{Flow cytometry quantification of BMPR1B, LHR, and FSHR}

The genotype effect on the density of BMPR1B expression in granulosa cells from small, medium, and large subordinate follicles of BB sheep was significantly higher than that in WT controls $(P<0.05, P<0.01$, and $P<0.005$ respectively, Fig. 5B).

Similarly, the density of FSHR was significantly increased in the BB sheep from the small antral follicle to the large follicle $(P<0.01, P<0.01$, and $P<0.005$ respectively), as shown in Fig. 5A, whereas the LHR

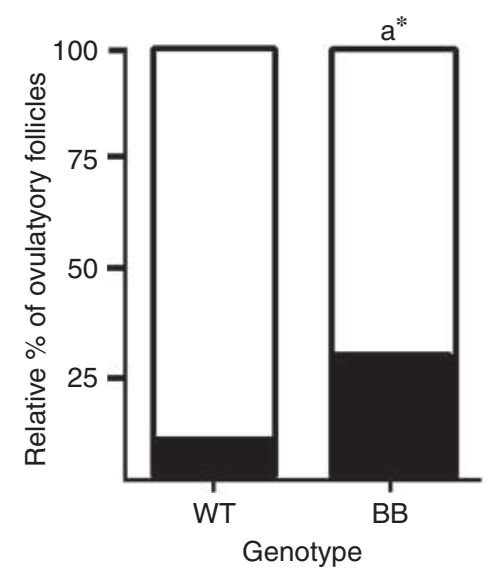

Figure 4 Relative frequency of ovulatory follicles for each genotype. The total number of follicles (clear section of bar) from $1 \mathrm{~mm}$ to the terminal end of folliculogenesis and ovulation, including corpora luteum $(\mathrm{CL})$, are presented for the BB and WT sheep. The ovulatory follicles (black section of bar), which are the largest follicles for the genotype, including $\mathrm{CL}$, provide evidence of the relative survival of recruited follicles for the WT and BB genotypes. The letter ' $a{ }^{* \prime}$ signifies a statistical difference in the retention of ovulatory follicles during folliculogenesis. Analysis of the contingency table using a two-tailed Fisher's exact test was performed with a $P$ value of 0.011 . 
density was greater only in the largest subordinate follicle ( $P<0.005$, Fig. 5C).

The WT sheep had elevated levels of FSHR in the largest of the subordinate follicles $(P<0.01)$, followed by down-regulation in the leading dominant follicles $(P<0.05$, Fig. 6A). The granulosa-luteal cells revealed
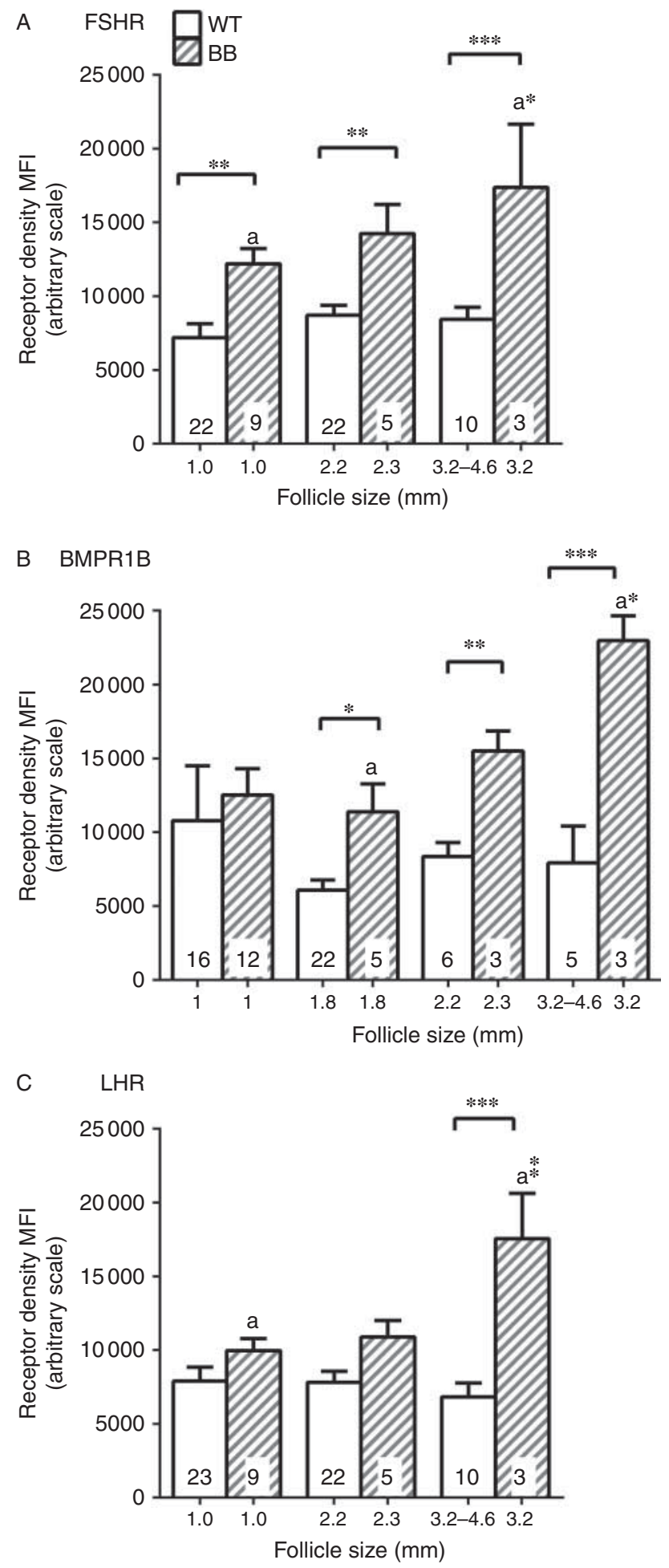

that the FSHR level after ovulation was significantly higher than the dominant pre-ovulatory follicle was, and this finding was maintained across the follicle sizes $(P<0.05$, Fig. 6A).

In the WT sheep, BMPR1B density was significantly decreased in a pattern of biphasic down-regulation, as was seen with the $1.8 \mathrm{~mm}$ subordinate follicle and the $4.4-7 \mathrm{~mm}$ dominant follicle $(P<0.05$ and $P<0.01$, Fig. 6B).

The granulosa-luteal cells from the sheep ovaries that had ovulated and contained one or more $C L$ revealed that the BMPR1B level after ovulation was significantly higher than the dominant pre-ovulatory follicles, and this finding was maintained across the follicle sizes $(P<0.05$, Fig. 6B).

LHR density was greater in the WT sheep, at $4.2 \mathrm{~mm}$, and it was down-regulated in the $4.6 \mathrm{~mm}$ subordinate follicle and the $4.4 \mathrm{~mm}$ dominant follicles $(P<0.05)$. The largest of the dominant follicles $(5-7 \mathrm{~mm})$ had similar levels of LHR density to those of the granulosa-luteal cells, whereas LHR expression increased and was then down-regulated in the smaller dominant follicles $(P<0.05$, Fig. 6C).

FSHR demonstrated a trend of increasing FSHR followed by a significant down-regulation of receptors in the dominant follicle and a significant up-regulation in the granulosa-luteal cells $(P<0.05$, Fig. $7 \mathrm{~A})$.

There was a significant steady increase from $1.0 \mathrm{~mm}$ to $3.2 \mathrm{~mm}$ in subordinate granulosa cell BMPR1B density with follicle size in BB sheep $(P<0.005$, Fig. $7 \mathrm{~B})$. The leading dominant follicles were down-regulated $(P<0.005)$, followed by a trend of increasing levels of BMPR1B in the granulosa-luteal cells.

LHR density was significantly increased from $1 \mathrm{~mm}$ to 3-3.2 mm $(P<0.01)$, followed by the down-regulation

Figure 5 Genotype comparison of WT and BB receptor density from granulosa cells from subordinate follicles. All of the follicles are subordinate follicles (i.e., the leading dominant follicle based on size and the granulosa-luteal follicles were not included because of the mutation-independent down-regulation; see the 'Materials and methods' section). (A) The average granulosa cell FSH receptor density, as measured by the mean fluorescent intensity (MFI) of $\sim 4000$ granulosa cells harvested from individual follicles, which were analyzed by immunofluorescent labeled flow cytometry for BB (striped) and WT (clear) genotypes. Exclusion gating based on positive FSHR signal and comparative size difference produced a uniform granulosa sample. The same gating was applied to all of the samples, and autofluorescence and nonspecific binding were removed by subtraction gating. (B) The average BMPR1B receptor density MFI for small antral follicles was divided into smaller-size classes to reflect the downregulation. (C) The average LHR density MFI for small antral follicles. Statistical verification using one-way ANOVA with uncorrected Fisher's LSD. Values are presented as means \pm S.E.M. $* P<0.05,{ }^{* *} P<0.01$, and ${ }^{* * *} P<0.001$. The letter ' $a$ ' signifies a statistical difference from the matching letter, and an attached asterisk (eg. $\mathrm{a}^{*}$ ) indicates the significance level for the size follicle. The number of subordinate follicles analyzed is shown for each follicle size class. 
of LHR density in the dominant pre-ovulatory follicles $(P<0.01$, Fig. $7 \mathrm{C})$. The granulosa-luteal cells demonstrated no significant difference from the down-regulated follicles of the dominant pre-ovulatory follicles in the BB sheep (Fig. 7C).
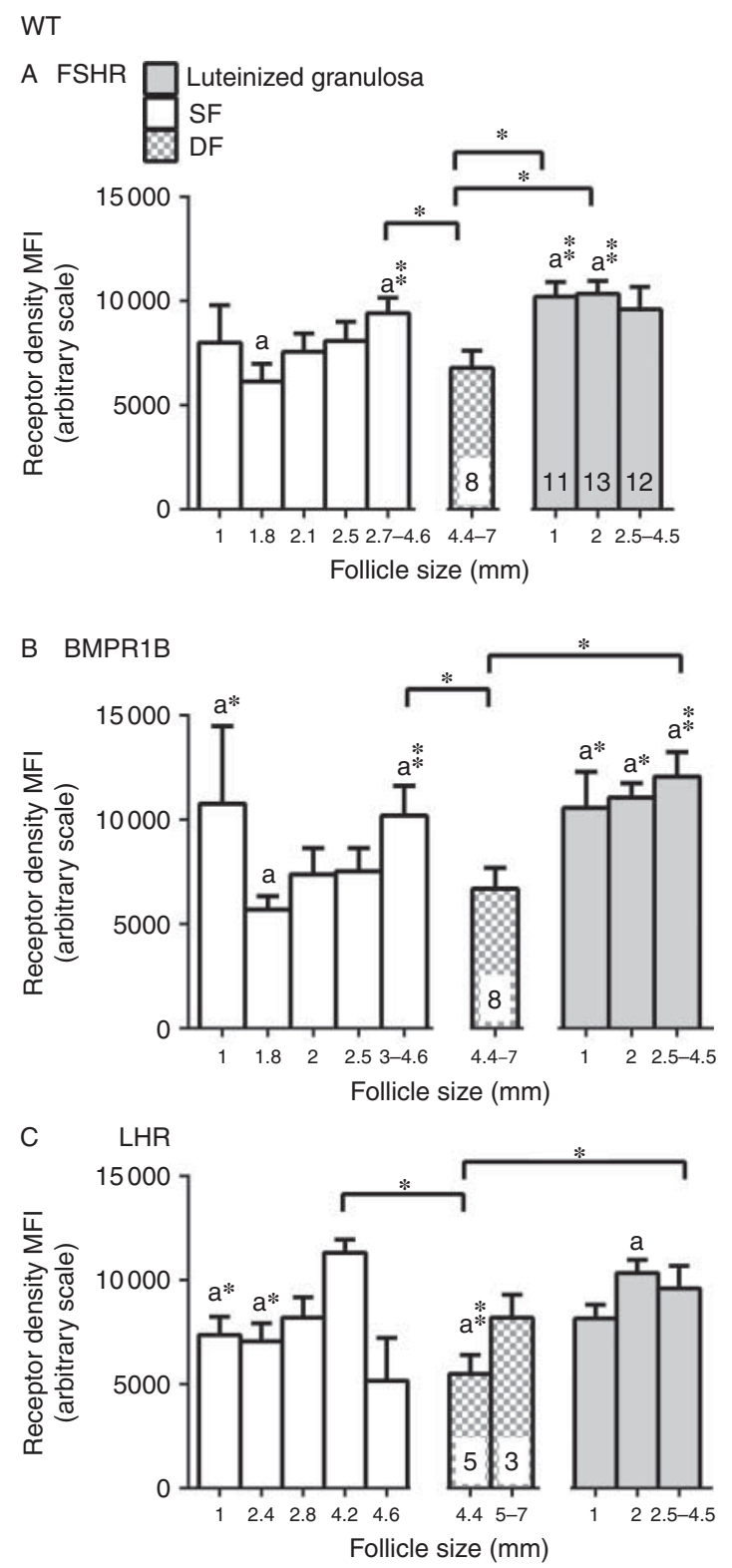

Figure 6 WT sheep receptor density and follicle size in granulosa cells from dominant as compared to subordinate and luteal follicles. Receptor density measured by mean fluorescent intensity (MFI) of subordinate (pre-ovulation) granulosa cells (clear), the (pre-ovulation) dominant follicle (checked), and (post-ovulation) granulosa-luteal cells (grey) for different follicle size groups for the WT genotype. (A) FSHR; (B) BMPR1B; and (C) LHR. Statistical verification using one-way ANOVA with uncorrected Fisher's LSD. Values are presented as means \pm S.E.M. ${ }^{*} P<0.05$ and ${ }^{* *} P<0.01$. The letter 'a' signifies a statistical difference from the matching letter, and an attached asterisk (eg. $a^{*}$ ) indicates the significance level for the size follicle. The number of dominant follicles and the number of follicles from ovulated sheep are indicated for each follicle size class.

\section{Flow cytometry quantification of apoptosis}

We report that the apoptosis and necrosis levels were significantly elevated in the largest of the subordinate follicles of the WT sheep $(P<0.01$, Fig. 8). The BB genotype did not demonstrate elevated levels in the largest of the subordinate follicles. The WT dominant follicle reported greater apoptosis and necrosis levels as compared to the $\mathrm{BB}$ dominant follicle of $3 \mathrm{~mm}$ (b, $P<0.05$, Fig. 9). An unusually large BB follicle was recorded, and the level of its apoptosis and necrosis was similar to the WT largest subordinate follicle of $40 \%$. The level of apoptosis and necrosis in the BB $1 \mathrm{~mm}$ follicles was greater post-ovulation as compared to the WT subordinate follicles $(\mathrm{c}, \mathrm{p}<0.05)$ but not as compared to the WT post-ovulation follicles (Fig. 9).

\section{Discussion}

The BMP signaling axis has been strongly associated with the gonadotropins $\mathrm{FSH}$ and $\mathrm{LH}$ in the pituitary-ovarian axis of control in the regulation of follicle recruitment, growth, and ovulation rate (Otsuka et al. 2001a, Miyoshi et al. 2006, Takeda et al. 2012). The BMP ligands 4, 6, 7, and 15 have been shown to have a stage-dependent high affinity to bind to the TGF $\beta$ type 1 receptor BMPR1B (Mazerbourg \& Hsueh 2006). The BB mutation that impacts the BMPR1B has been studied extensively, but the findings have mainly focused on the indirect heightened physiological responsiveness of BB sheep as compared to WT controls (McNatty et al. 1985, Campbell et al. 2006, Fabre et al. 2006).

In the present study's novel approach, the mature cell surface proteins for FSHR, LHR, and BMPR1B were measured by flow cytometric analysis. Immunolabeled granulosa cells were collected from individual antral follicles and were harvested in situ to reduce contamination with other ovarian or blood cells. The receptor density was quantified by the average fluorescence intensity of $\sim 4000$ isolated granulosa cells/follicle (Fig. 1). The selected antibodies were previously validated by immunolocalization in sheep by our research group (AI-Samerria \& Almahbobi 2014). Positive and negative signals were used to subtract autofluorescence and nonspecific binding, whereas the uniqueness of the FSHR on granulosa cells and the relative sizes of the other cells positively identified the population of granulosa cells (Fig. 1).

The receptor density of BMPR1B, FSHR, and LHR was significantly increased in the granulosa cells of developing antral follicles of BB sheep (five) as compared to the WT sheep (12) (Fig. 5). Furthermore, the leading dominant follicle from both genotypes had reduced receptor density as compared to the subordinate follicles, which indicates a vital prerequisite down-regulation before ovulation (Figs 6 and 7). A direct in vivo quantitative analysis between the genotype for BMPR1B and LHR expression has been 
BB

A
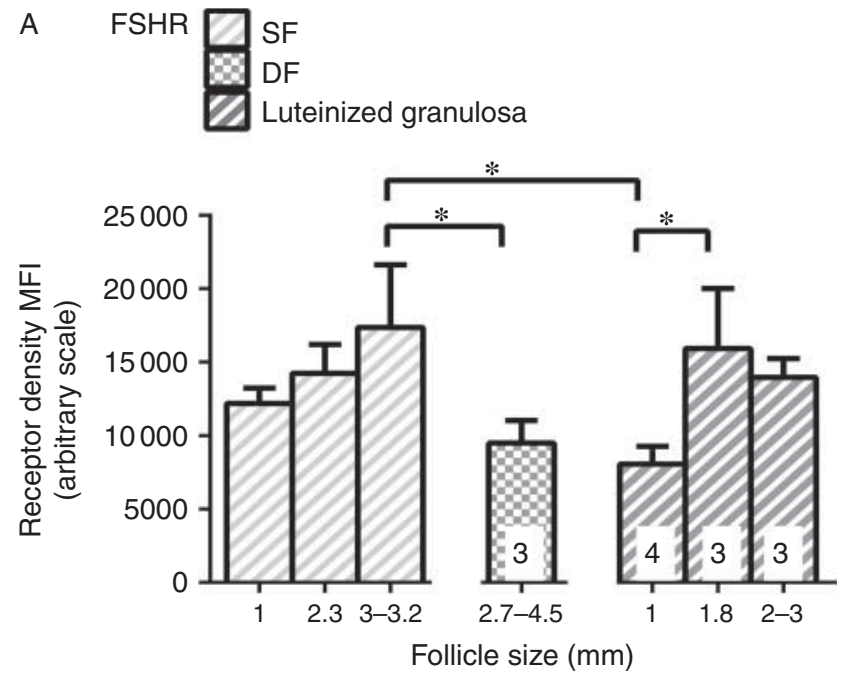

B BMPR1B
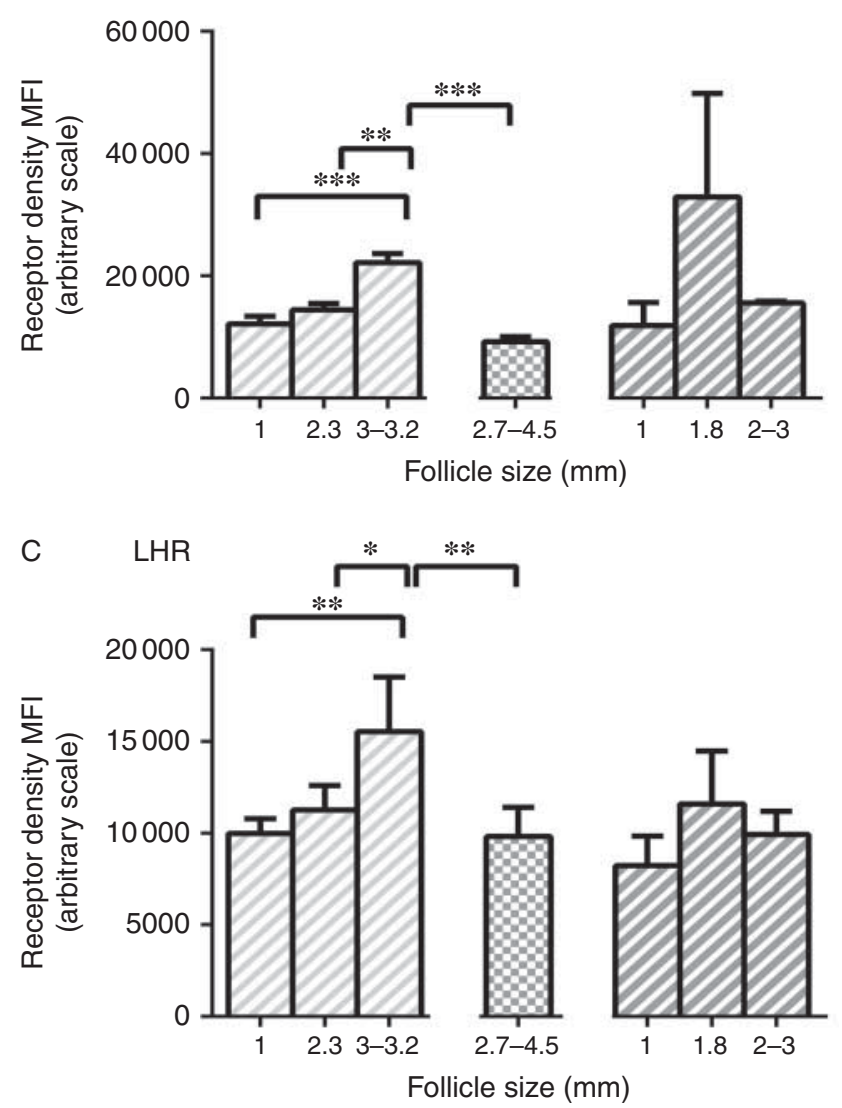

Figure 7 Booroola (BB) receptor density and follicle size in granulosa cells from dominant as compared to subordinate and luteal follicles. Receptor density measured by mean fluorescent intensity (MFI) of subordinate (pre-ovulation) granulosa cells (clear), the (pre-ovulation) dominant follicle (checked), and (post-ovulation) granulosa-luteal cells (grey) for different follicle size groups for the WT genotype. (A) FSHR; (B) BMPR1B; and (C) LHR. Statistical verification using one-way ANOVA with uncorrected Fisher's LSD. Values are presented as means \pm S.E.M. ${ }^{*} P<0.05,{ }^{* *} P<0.01$, and ${ }^{* * *} P<0.001$. The number of dominant follicles and the number of follicles from ovulated sheep are indicated for each follicle size class. previously reported, with the acknowledged limitations of follicle class and sensitivity of the technique (McNatty et al. 1986a, Mulsant et al. 2001). Previously, qualitative data reported that the level of $B M P R 1 B$ mRNA in follicles from 1 to $3 \mathrm{~mm}$ antral follicles indicated that BMPR1B mRNA was not reduced in BB sheep (Mulsant et al. 2001). Recently, quantitative findings have shown the level of $B M P R 1 B$ mRNA in 1-3 mm follicles to be equivalent in BB sheep (Estienne et al. 2015), but this is not consistent with the present findings. In the Estienne et al. (2015) study, the follicles were divided into small $(1-3 \mathrm{~mm})$ and large (3-5 $\mathrm{mm}$ ) groups, which prevented an accurate comparison of the genotype effect because of the large range of development within the $1-3 \mathrm{~mm}$ range (McNatty et al. 1985) and because of the down-regulation of the leading dominant follicle in the $3-5 \mathrm{~mm}$ range (Gasperin et al. 2014). It has been reported previously (McNatty et al. 1986b) that BB follicles reach steroidogenic capacity at $2-2.5 \mathrm{~mm}$ as compared to the WT follicles at $4-4.5 \mathrm{~mm}$. The pooling of follicles would mask the cellular changes that take place during the follicular development in this range. In addition, in the present study, translated mature FSHR, BMPR1B, and LHR proteins were measured as opposed to measuring the mRNA for the receptor. Differences may therefore have resulted, seeing as the mRNA measurement would also include immature and mature proteins that are potentially not expressed (Ascoli et al. 2002).

\section{Pattern of biphasic down-regulation in WT sheep}

An unexpected finding of the present study was the reduction in the density of BMPR1B in the WT follicles at two stages of folliculogenesis (Fig. 6B). The density of BMPR1B was elevated at the time of divergence $(1-1.7 \mathrm{~mm})$ and then down-regulated after dominant follicle selection $(1.8 \mathrm{~mm})$, which led to a steady increase in density to a peak in the largest of the subordinate follicles (3-4.6 mm) (Fig. 6B). In both the BB sheep and the WT sheep, the leading dominant follicle $(4.4-7 \mathrm{~mm})$ had a significantly reduced density of receptors, which demonstrated the presence of a hierarchical organization of the follicles that has been reported to be present in sheep (Figs 6B and 7B) (Evans et al. 2002, Gasperin et al. 2014).

Chen et al. (2009) and Estienne et al. (2015) have also reported that the WT granulosa cells have increasing BMPR1B with increased follicle size, which is consistent with the present finding of an increased density of BMPR1B in subordinate follicles from 1.8 to $4.6 \mathrm{~mm}$, which was the largest size of the subordinate follicles $(P<0.010$, Fig. 6B).

In the present study, the high BMPR1B in the BB follicles was not present in the 1-1.7 mm follicle, possibly because of the earlier onset of development, which is typical of the BB genotype (McNatty et al. 1985). The high level of receptor density may have occurred at a smaller BB follicle size of $<1 \mathrm{~mm}$. In the BB, however, the downregulation of the dominant follicle was comparable to 


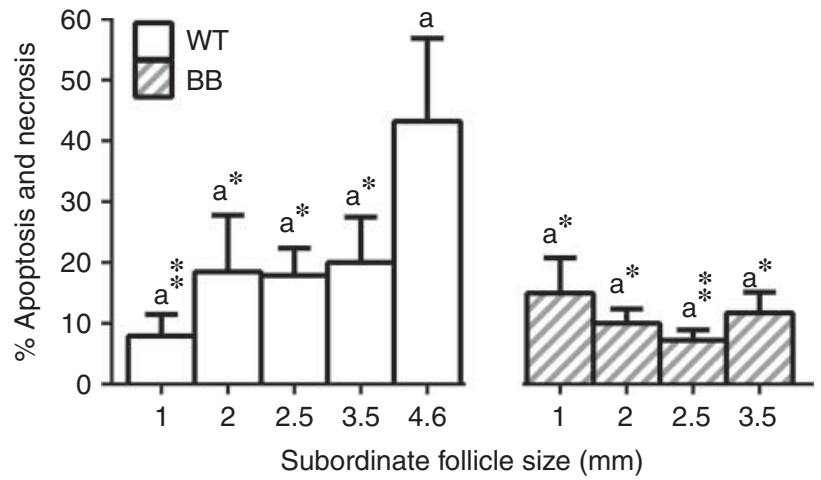

Figure 8 WT sheep compared to BB genotype: \% apoptosis and necrosis of granulosa cells from subordinate follicles. All of the follicles are subordinate follicles (i.e., the leading dominant follicle based on size was not included because of the mutation-independent downregulation). Statistical verification using one-way ANOVA with uncorrected Fisher's Least Significant Different (LSD). Values are presented as means \pm S.E.M. ${ }^{*} P<0.05$ and ${ }^{* *} P<0.01$. The letter ' $a$ ' signifies a statistical difference from the matching letter, and an attached asterisk (eg. $\mathrm{a}^{*}$ ) indicates the significance level for the size follicle.

the WT, albeit at a reduced size (Fig. 7). It is therefore apparent that the down-regulation mechanism is independent of the mutation, seeing as it occurred in both genotypes. The BMPs 4, 6, 7, and 15 signal via the BMPR1B, and they have been previously shown to play a regulatory role in the suppression of progesterone production before ovulation (Ryan et al. 2008, Takeda et al. 2012). The up-regulation of ERK $1 / 2$ signaling (Fan et al. 2009) occurs coincident with the down-regulation of BMPR1B activity, which suppresses progesterone synthesis (Miyoshi et al. 2006, Feary et al. 2007). The failure to down-regulate BMPR1B activity would therefore impede the process of luteinization and prevent maturation of the follicle (Gordon et al. 2008).

\section{Gonadotropin regulation and FSHR signaling}

FSHR and LHR were found to be greater in follicles from another prolific breed (Romanov) as compared to île-de-France ewes and in the Chinese prolific Small Tail Han sheep with a mutation of the BMPR1B gene (Abdennebi et al. 1999, Jia et al. 2007). The quantitative data from the present research confirm and expand these observations, and they propose that the mutationinduced changes to BMPR1B signaling in BB sheep are responsible for the significantly up-regulated density of BMPR1B, FSHR, and LHR, and they have a cumulative effect as the follicle increases in size (Fig. 5).

Quantitative genotype data on FSHR have not been previously reported, although FSH stimulation and granulosa cell responsiveness in BB sheep have been reported (Henderson et al. 1985). Moreover, the BMP2, 4 , and 7 ligands in the WT goat and human have been shown to increase the level of FSHR mRNA, whereas
BMP6 was shown to increase LHR mRNA, which indicates a direct role for BMPs in the regulation of receptor density (Ogura Nose et al. 2012, Zhu et al. 2013). Ovine granulosa cells cultured with both FSH and estrogen increased the expression of BMPR1B (Chen et al. 2009), which supports the present findings of increased BMPR1B density in the growing subordinate follicles and the reduced BMPR1B activity observed in the down-regulation of FSHR and BMPR1B in preparation for ovulation of the dominant follicle (Chen et al. 2009). In another study, FSH and BMP ligand-induced production of estrogen was significantly increased in the $\mathrm{BB}$ as compared to the WT, which is also supportive of the present findings of an increased density of FSHR and LHR in the BB (Fig. 5; Campbell et al. 2006).

In support of the dynamic role of BMPs, it has also been shown that BMP6 reduces post-dominant follicle selection in the rat, and this selection is reduced completely in the ovulating dominant follicle (Erickson \& Shimasaki 2003). Similarly, BMP15 and BMPR1B activity in the oocyte has been shown to be down-regulated before ovulation in sheep (Feary et al. 2007). Furthermore, in cultured rat granulosa cells, BMP15 reduced the expression of FSHR mRNA (Otsuka et al. 2001a). It is therefore possible that the attenuating mutation of the BMPR1B signal may reduce the suppression and lead to the up-regulation of FSHR in the BB (Otsuka et al. 2001b).

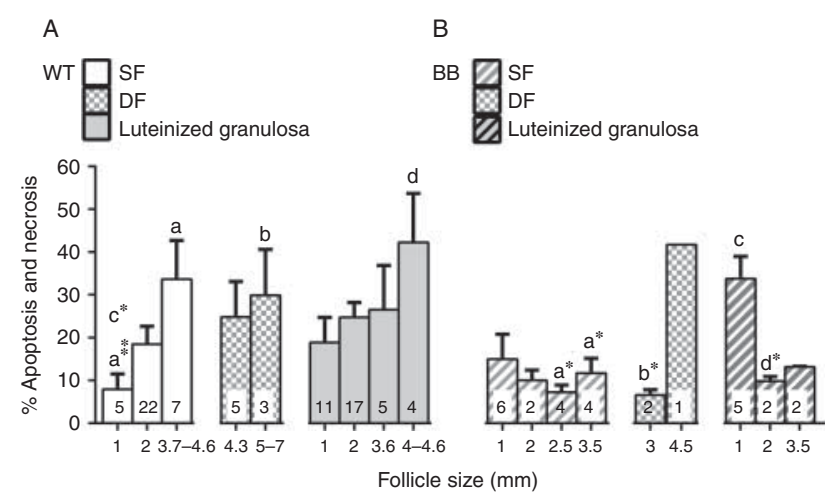

Figure 9 (A) WT sheep comparison of \% apoptosis and necrosis in granulosa cells from dominant as compared to subordinate and luteal follicles. Apoptosis and necrosis of subordinate (pre-ovulation) granulosa cells (clear), the (pre-ovulation) dominant follicle (checked), and (post-ovulation) granulosa-luteal cells (grey) of different follicle size classes for the WT genotype. (B) BB sheep comparison of apoptosis and necrosis in granulosa cells from dominant as compared to subordinate follicles and granulosa-luteal cells. Apoptosis and necrosis of subordinate (pre-ovulation) granulosa cells (clear), the (pre-ovulation) dominant follicle (checked), and post-ovulation granulosa-luteal cells (grey) of different follicle size classes for the BB genotype. Statistical verification using one-way ANOVA with uncorrected Fisher's LSD.

Values are presented as means \pm S.E.M. ${ }^{*} P<0.05,{ }^{* *} P<0.01$. The letter such as ' $a$ ' signifies a statistical difference from the matching letter, and an attached asterisk (eg. $\mathrm{a}^{*}$ ) indicates the significance level for the size follicle. The number of follicles is indicated for each follicle size class. 


\section{Down-regulation in peri-luteal and $C L$}

In human subjects, BMP2, 6, 7, and 15 were all shown to increase FSHR mRNA (Ogura Nose et al. 2012). The granulosa cells, however, were not cultured in serum-free culture and therefore spontaneously luteinized. This was acknowledged by the authors of the paper, insofar as they suggested that the cells were not representative of granulosa cells but were rather granulosa-luteal cells. A reduction in BMP inhibition therefore seems to be an initiating change toward luteinization. The brief stage-specific, peri-ovulatory decline in estrogen production coincides with the cessation of mitogenic growth and steroidogenic differentiation (Komar et al. 2001). In the present study, the follicles that were not destined to ovulate continued to express a high density of receptors across all sizes in the WT, whereas they were inconsistent in the BB (Figs 6 and 7). The possible mechanism involved may be related to the ability of the BB to prepare multiple follicles for ovulation.

\section{Steroidogenic differentiation and LHR earlier acquisition}

In the past, it has been recognized that the increase in the ovulation rate in BB sheep is a result of to the follicles being more sensitive to FSH at an earlier follicle size (McNatty et al. 1985, Baird \& Campbell 1998). The previously reported increased sensitivity to both FSH and $\mathrm{LH}$ can be attributed to the novel findings in the present study of an increased density of the mature FSHR and LHR at the cell surface, which has not previously been reported (Fig. 5A and $\mathrm{C}$ ). In particular, the cAMP response to $\mathrm{FSH}$ and $\mathrm{LH}$ stimulation was previously shown to increase at $>3-4$ and $>2-3 \mathrm{~mm}$ respectively in the $\mathrm{BB}$, which is consistent with the present findings (Fig. 5A and C; Henderson et al. 1985).

The up-regulation of LHR provides expanded evidence of an earlier acquisition of receptors with greater expression density at an earlier follicle size of $3 \mathrm{~mm}$ in the $\mathrm{BB}$ as compared to $4.2 \mathrm{~mm}$ in the WT genotype (Figs 6C and 7C). Furthermore, we demonstrated that LHRs are present in granulosa cells from antral follicles. This was previously reported to be first expressed in secondary follicles in humans, but it was not observed in the rodent until late antral stage (Camp et al. 1991, Yung et al. 2014).

Consistent with other authors, LHR density in the present study was accelerated in the pre-ovulatory follicle in the WT and the BB, and it was followed by a significant reduction in the leading dominant follicle of each animal (Figs 6C and 7C; LaPolt et al. 1992, Jeppesen et al. 2012, Ophir et al. 2014).

The ovine granulosa cells in the present study would have been exposed to the $\mathrm{LH}$ surge that initiates cytoskeletal reorganization, the cessation of proliferation, and the alteration of steroidogenic capacity. The process of luteinization appears to rely on LHR down-regulation of the leading dominant follicles (Fig. 7B; Izadyar et al. 1998, Fan et al. 2009).

\section{Ovulation rate and apoptosis}

There are several ways in which a high prolificacy breed increases ovulation rate, and it appears that BB follicles may mature early because of an increased receptor density and a reduction in atretic follicles or apoptosis, as was reported in the present study and previous studies (Driancourt et al. 1985, McNatty et al. 1986b, Estienne et al. 2015). The increased FSHR and the ability to wait up to 2 days allowed the subordinate follicles to continue to grow, which resulted in the threefold increase in the terminal end follicles that was reported in the present study (Fig. 4) and by others (Driancourt et al. 1985, McNatty et al. 1986b). It was indeed evident that post-ovulation BB sheep produced three $\mathrm{CL}$ and that the very large BB pre-ovulatory follicle of $4.5 \mathrm{~mm}$ had not ovulated, possibly because the next subordinate follicle was only $2.4 \mathrm{~mm}$, which thereby delayed ovulation (Fig. 9; Driancourt et al. 1985, McNatty et al. 1986b). The prolonged delay may have initiated the exceptionally high level of apoptosis and necrosis that was observed, seeing as the size of the follicle was not typical for the genotype.

Our finding of significantly less apoptosis and necrosis in the pre-ovulatory follicles of the BB is consistent with the number of follicles that were recorded as being at the ovulatory size in the BB, which was three times the amount that remained in the WT (Table 3; Figs 8 and 9). The high level of apoptosis and necrosis in the largest of the subordinate follicles in the WT is supportive of the increased rate of follicle loss and results in fewer ovulations than the BB (Fig. 4). Moreover, the WT dominant and luteal follicles continued to have high levels of cell death, whereas in the BB, the levels were generally low pre- and post-ovulation (Fig. 9). It is important to note that in the present study, we did not exclude any follicles on the basis of estrogen production or morphological indications of programmed DNA fragmentation, because previous findings demonstrated that the LHR binding assays revealed no differences between the follicles that were determined to be atretic and those that were deemed non-atretic in the same size class (McNatty et al. 1986a). Furthermore, it has also been reported more recently that granulosa cell apoptosis (which is indicated by DNA fragmentation and cytoplasmic blebbing) can be present with functional steroidogenic mitochondria (Amsterdam et al. 2003). It is, however, acknowledged that the levels of follicle apoptosis and cell DNA fragmentation are lower in antral follicles with greater estrogen production than androgen production (Yuan \& Giudice 1997). The reduction in $\mathrm{BB}$ apoptosis may be a result of the maintained elevated levels of FSH after divergence as compared to the declining FSH in the WT (Baird 1987) or 
a result of the increased FSHR density being more responsive to the available FSH levels.

In conclusion, these results provide further insight into the mechanism that governs the interaction between gonadotropins and intra-ovarian BMPs in the regulation of ovulation rate. These results are significant and central to the development of a new clinical approach to improve human female fertility. Rather than focusing on increasing a patient's response to exogenous gonadotropins, in order to increase the ovulation rate, a targeted approach could be incorporated by manipulating the signaling pathways of BMPs. A new approach would be particularly beneficial to subfertile patients who respond poorly to gonadotropin stimulation.

\section{Declaration of interest}

The authors declare that there is no conflict of interest that could be perceived as prejudicing the impartiality of the research reported.

\section{Funding}

S L P Regan was the recipient of an Australian Postgraduate Award and a Curtin University Postgraduate Scholarship. This research did not receive any specific grant from any funding agency in the public, commercial or not-for-profit sector.

\section{Acknowledgements}

We would like to thank the CSIRO in Armidale, New South Wales, Australia, for its assistance in the use of flow cytometry and other technical assistance.

\section{References}

Abdennebi L, Monget P, Pisselet C, Remy JJ, Salesse R \& Monniaux D 1999 Comparative expression of luteinizing hormone and follicle-stimulating hormone receptors in ovarian follicles from high and low prolific sheep breeds. Biology of Reproduction 60 845-854. (doi:10.1095/biolreprod60.4.845)

Abir R, Ben-Haroush A, Melamed N, Felz C, Krissi H \& Fisch B 2008 Expression of bone morphogenetic proteins 4 and 7 and their receptors IA, IB, and II in human ovaries from fetuses and adults. Fertility and Sterility 89 1430-1440. (doi:10.1016/j.fertnstert.2007.04.064)

Al-Samerria SA \& Almahbobi G 2014 Three-dimensional image analysis to quantify the temporo-spacial expression of cellular receptors. Journal of Medical and Bioengineering 3 179-182. (doi:10.12720/ jomb.3.3.179-182)

Amsterdam A, Sasson R, Keren Tal I, Aharoni D, Dantes A, Rimon E, Land A, Cohen T, Dor Y \& Hirsh L 2003 Alternative pathways of ovarian apoptosis: death for life. Biochemical Pharmacology 66 1355-1362. (doi:10.1016/S0006-2952(03)00485-4)

Andersen CY, Westergaard LG, Figenschau Y, Bertheussen K \& Forsdahl F 1993 Endocrine composition of follicular fluid comparing human chorionic gonadotrophin to a gonadotrophin-releasing hormone agonist for ovulation induction. Human Reproduction 8 840-843.

Andersen CY, Schmidt KT, Kristensen SG, Rosendahl M, Byskov AG \& Ernst E 2010 Concentrations of $\mathrm{AMH}$ and inhibin-B in relation to follicular diameter in normal human small antral follicles. Human Reproduction 25 1282-1287. (doi:10.1093/humrep/deq019)
Ascoli M, Fanelli F \& Segaloff DL 2002 The lutropin/choriogonadotropin receptor, a 2002 perspective. Endocrine Reviews 3 141-174. (doi:10. 1210/edrv.23.2.0462)

Baird DT 1987 A model for follicular selection and ovulation: lessons from superovulation. Journal of Steroid Biochemistry 27 15-23. (doi:10.1016/ 0022-4731(87)90289-5)

Baird DT \& Campbell BK 1998 Follicle selection in sheep with breed differences in ovulation rate. Molecular and Cellular Endocrinology 145 89-95. (doi:10.1016/S0303-7207(98)00174-9)

Cai J, Lou H, Dong M, Lu X, Zhu Y, Gao H \& Huang H 2007 Poor ovarian response to gonadotropin stimulation is associated with low expression of follicle-stimulating hormone receptor in granulosa cells. Fertility and Sterility 87 1350-1356. (doi:10.1016/j.fertnstert.2006.11.034)

Camp TA, Rahal JO \& Mayo KE 1991 Cellular localization and hormonal regulation of follicle-stimulating hormone and luteinizing hormone receptor messenger RNAs in the rat ovary. Molecular Endocrinology 5 1405-1417. (doi:10.1210/mend-5-10-1405)

Campbell BK, Baird DT, Souza CJH \& Webb R 2003 The FecB (Booroola) gene acts at the ovary: in vivo evidence. Reproduction 126 101-111. (doi:10.1530/rep.0.1260101)

Campbell BK, Souza CJH, Skinner AJ, Webb R \& Baird DT 2006 Enhanced response of granulosa and theca cells from sheep carriers of the FecB mutation in vitro to gonadotropins and bone morphogenic protein-2, -4, and -6. Endocrinology 147 1608-1620. (doi:10.1210/en.2005-0604)

Chen AQ, Yu SD, Wang ZG, Xu ZR \& Yang ZG 2009 Stage-specific expression of bone morphogenetic protein type I and type II receptor genes: effects of follicle-stimulating hormone on ovine antral follicles. Animal Reproduction Science 111 391-399. (doi:10.1016/j.anireprosci.2008.03.011)

Crawford J, Heath D, Reader K, Quirke L, Hudson N, Juengel J \& McNatty K 2011 Oocytes in sheep homozygous for a mutation in bone morphogenetic protein receptor $1 \mathrm{~B}$ express lower mRNA levels of bone morphogenetic protein 15 but not growth differentiation factor 9 . Reproduction 142 53-61. (doi:10.1530/REP-10-0485)

Cummins LJ, O'Shea T, Bindon BM, Lee VW \& Findlay JK 1983 Ovarian inhibin content and sensitivity to inhibin in Booroola and control strain Merino ewes. Journal of Reproduction and Fertility 67 1-7. (doi:10.1530/ jrf.0.0670001)

Demchenko A 2013 Beyond annexin V: fluorescence response of cellular membranes to apoptosis. Cytotechnology 65 157-172. (doi:10.1007/ s10616-012-9481-y)

Driancourt MA, Cahill LP \& Bindon BM 1985 Ovarian follicular populations and preovulatory enlargement in Booroola and control Merino ewes. Journal of Reproduction and Fertility 73 93-107. (doi:10.1530/jrf.0. 0730093)

Erickson G \& Shimasaki S 2003 The spatiotemporal expression pattern of the bone morphogenetic protein family in rat ovary cell types during the estrous cycle. Reproductive Biology and Endocrinology 19. (doi:10.1186/1477-7827-1-9)

Estienne A, Pierre A, di Clemente N, Picard JY, Jarrier P, Mansanet C, Monniaux D \& Fabre S 2015 Anti-Müllerian hormone regulation by the bone morphogenetic proteins in the sheep ovary: deciphering a direct regulatory pathway. Endocrinology 156 301-313. (doi:10.1210/en. 2014-1551)

Evans ACO 2003 Ovarian follicle growth and consequences for fertility in sheep. Animal Reproduction Science 78 289-306. (doi:10.1016/S03784320(03)00096-4)

Evans ACO, Flynn JD, Duffy P, Knight PG \& Boland MP 2002 Effects of ovarian follicle ablation on FSH, oestradiol and inhibin A concentrations and growth of other follicles in sheep. Reproduction 123 59-66. (doi:10.1530/rep.0.1230059)

Fabre S, Pierre A, Mulsant P, Bodin L, Di Pasquale E, Persani L, Monget P \& Monniaux D 2006 Regulation of ovulation rate in mammals: contribution of sheep genetic models. Reproductive Biology and Endocrinology 4 20. (doi:10.1186/1477-7827-4-20)

Fan H, Liu Z, Shimada M, Sterneck E, Johnson PF, Hedrick SM \& Richards JS 2009 MAPK3/1 (ERK1/2) in ovarian granulosa cells are essential for female fertility. Science 324 938-941. (doi:10.1126/science.1171396)

Feary E, Juengel J, Smith P, French M, O'Connell A, Lawrence S, Galloway S, Davis G \& McNatty K 2007 Patterns of expression of messenger RNAs encoding GDF9, BMP15, TGFBR1, BMPR1B, and BMPR2 during follicular 
development and characterization of ovarian follicular populations in ewes carrying the Woodlands FecX2W mutation. Biology of Reproduction 77 990-998. (doi:10.1095/biolreprod.107.062752)

Fry RC, Clarke IJ, Cummins JT, Bindon BM, Piper LR \& Cahill LP 1988 Induction of ovulation in chronically hypophysectomized Booroola ewes. Journal of Reproduction and Fertility 82 711-715. (doi:10.1530/jrf. 0.0820711 )

Gao S, De Geyter C, Kossowska K \& Zhang H 2007 FSH stimulates the expression of the ADAMTS-16 protease in mature human ovarian follicles. Molecular Human Reproduction 13 465-471. (doi:10.1093/ molehr/gam037)

Gasperin BG, Ferreira R, Rovani MT, Bordignon V, Duggavathi R, Buratini J, Oliveira JF \& Gonçalves PB 2014 Expression of receptors for BMP15 is differentially regulated in dominant and subordinate follicles during follicle deviation in cattle. Animal Reproduction Science 144 72-78. (doi:10.1016/j.anireprosci.2013.12.002)

Ginther OJ, Beg MA, Gastal EL, Gastal MO, Baerwald AR \& Pierson RA 2005 Systemic concentrations of hormones during the development of follicular waves in mares and women: a comparative study. Reproduction 130 379-388. (doi:10.1530/rep.1.00757)

Gordon A, Garrido-Gracia JC, Aguilar R, Bellido C, Velasco JA, Millan Y, Tena-Sempere M, Martín de las Mulas J \& Sánchez-Criado JE 2008 The ovary-mediated FSH attenuation of the LH surge in the rat involves a decreased gonadotroph progesterone receptor (PR) action but not PR expression. Journal of Endocrinology 196 583-592. (doi:10.1677/ JOE-07-0223)

Haÿ E, Lemonnier J, Fromigué O, Guénou H \& Marie PJ 2004 Bone morphogenetic protein receptor IB signaling mediates apoptosis independently of differentiation in osteoblastic cells. Journal of Biological Chemistry 279 1650-1658. (doi:10.1074/jbc.M300969200)

Hampton JH, Bader JF, Lamberson WR, Smith MF, Youngquist RS \& Garverick HA 2004 Gonadotropin requirements for dominant follicle selection in GnRH agonist-treated cows. Reproduction 127 695-703. (doi:10.1530/rep.1.00015)

Henderson KM, Kieboom LE, McNatty KP, Lun S \& Heath D 1985 Gonadotrophin-stimulated cyclic AMP production by granulosa cells from Booroola $\times$ Romney ewes with and without a fecundity gene. Journal of Reproduction and Fertility 75 111-120. (doi:10.1530/jrf.0. 0750111)

Hudson NL, O'Connell AR, Shaw L, Clarke IJ \& McNatty KP 1999 Effect of exogenous FSH on ovulation rate in homozygous carriers or noncarriers of the Booroola FecB gene after hypothalamic-pituitary disconnection or after treatment with a GnRH agonist. Domestic Animal Endocrinology 16 69-80. (doi:10.1016/S0739-7240(98)00045-9)

Izadyar F, Zeinstra E \& Bevers MM 1998 Follicle-stimulating hormone and growth hormone act differently on nuclear maturation while both enhance developmental competence of in vitro matured bovine oocytes. Molecular Reproduction and Development 51 339-345. (doi:10.1002/ (SICl)1098-2795(199811)51:3<339::AID-MRD14>3.0.CO;2-Y)

Jakimiuk AJ, Weitsman SR, Yen H-W, Bogusiewicz M \& Magoffin DA 2002 Estrogen receptor $\alpha$ and $\beta$ expression in theca and granulosa cells from women with polycystic ovary syndrome. Journal of Clinical Endocrinology and Metabolism 87 5532-5538. (doi:10.1210/jc.2002-020323)

Jeppesen JV, Kristensen SG, Nielsen ME, Humaidan P, Dal Canto M, Fadini R, Schmidt KT, Ernst E \& Yding Andersen C 2012 LH-receptor gene expression in human granulosa and cumulus cells from antral and preovulatory follicles. Journal of Clinical Endocrinology and Metabolism 97 E1524-E1531. (doi:10.1210/jc.2012-1427)

Jia C-I, Li N, Wei Z-h, Zhu X-p, Liu H-y \& Jia Z-h 2007 Study on FSHR and LHR mRNA levels of different BMPRIB genotypes of small tail han sheep during the oestrum. Agricultural Sciences in China 6 94-99. (doi:10. 1016/S1671-2927(07)60021-2)

Knight PG \& Glister C 2006 TGF- $\beta$ superfamily members and ovarian follicle development. Reproduction 132 191-206. (doi:10.1530/rep.1. 01074)

Komar CM, Berndtson AK, Evans ACO \& Fortune JE 2001 Decline in circulating estradiol during the periovulatory period is correlated with decreases in estradiol and androgen, and in messenger RNA for P450 aromatase and P450 $17 \alpha$-hydroxylase, in bovine preovulatory follicles. Biology of Reproduction 64 1797-1805. (doi:10.1095/biolreprod64.6.1797)

LaPolt PS, Tilly JL, Aihara T, Nishimori K \& Hsueh AJ 1992 Gonadotropininduced up- and down-regulation of ovarian follicle-stimulating hormone $(\mathrm{FSH})$ receptor gene expression in immature rats: effects of pregnant mare's serum gonadotropin, human chorionic gonadotropin, and recombinant FSH. Endocrinology 130 1289-1295.

Mazerbourg S \& Hsueh AJ 2006 Genomic analyses facilitate identification of receptors and signalling pathways for growth differentiation factor 9 and related orphan bone morphogenetic protein/growth differentiation factor ligands. Human Reproduction Update 12 373-383. (doi:10.1093/ humupd/dml014)

McNatty KP \& Henderson KM 1987 Gonadotrophins, fecundity genes and ovarian follicular function. Journal of Steroid Biochemistry 27 365-373. (doi:10.1016/0022-4731(87)90329-3)

McNatty KP, Henderson KM, Lun S, Heath DA, Ball K, Hudson NL, Fannin J, Gibb M, Kieboom LE \& Smith P 1985 Ovarian activity in Booroola $\times$ Romney ewes which have a major gene influencing their ovulation rate. Journal of Reproduction and Fertility 73 109-120. (doi:10. 1530/jrf.0.0730109)

McNatty KP, O'Keeffe LE, Henderson KM, Heath DA \& Lun S $1986 a^{125}$ Ilabelled hCG binding characteristics in theca interna and other tissues from Romney ewes and from Booroola $\times$ Romney ewes with and without a major gene influencing their ovulation rate. Journal of Reproduction and Fertility 77 477-488. (doi:10.1530/jrf.0.0770477)

McNatty K, Lun S, Heath D, Ball K, Smith P, Hudson N, McDiarmid J, Gibb M \& Henderson K $1986 b$ Differences in ovarian activity between Booroola Merino ewes which were homozygous, heterozygous and non-carriers of a major gene influencing their ovulation rate. Journal of Reproduction and Fertility 77 193-205. (doi:10.1530/jrf.0. 0770193)

Mihm M \& Evans ACO 2008 Mechanisms for dominant follicle selection in monovulatory species: a comparison of morphological, endocrine and intraovarian events in cows, mares and women. Reproduction in Domestic Animals 43 48-56. (doi:10.1111/j.14390531.2008.01142.x)

Miyoshi T, Otsuka F, Suzuki J, Takeda M, Inagaki K, Kano Y, Otani H, Mimura Y, Ogura T \& Makino H 2006 Mutual regulation of folliclestimulating hormone signaling and bone morphogenetic protein system in human granulosa cells. Biology of Reproduction 74 1073-1082. (doi:10.1095/biolreprod.105.047969)

Mulsant P, Lecerf F, Fabre S, Schibler L, Monget P, Lanneluc I, Pisselet C, Riquet J, Monniaux D, Callebaut I et al. 2001 Mutation in bone morphogenetic protein receptor-IB is associated with increased ovulation rate in Booroola Mérino ewes. PNAS 98 5104-5109. (doi:10.1073/pnas.091577598)

Ogura Nose S, Yoshino O, Osuga Y, Shi J, Hiroi H, Yano T \& Taketani Y 2012 Anti-Müllerian hormone $(\mathrm{AMH})$ is induced by bone morphogenetic protein (BMP) cytokines in human granulosa cells. European Journal of Obstetrics, Gynecology, and Reproductive Biology 164 44-47. (doi:10. 1016/j.ejogrb.2012.05.017)

Ophir L, Yung Y, Maman E, Rubinstein N, Yerushalmi GM, Haas J, Barzilay E \& Hourvitz A 2014 Establishment and validation of a model for non-luteinized human mural granulosa cell culture. Molecular and Cellular Endocrinology 384 165-174. (doi:10.1016/j. mce.2014.01.018)

Otsuka F 2010 Multiple endocrine regulation by bone morphogenetic protein system. Endocrine Journal 57 3-14. (doi:10.1507/endocrj. K09E-310)

Otsuka F, Yamamoto S, Erickson G \& Shimasaki S 2001a Bone morphogenetic protein-15 inhibits follicle-stimulating hormone (FSH) action by suppressing FSH receptor expression. Journal of Biological Chemistry 276 11387-11392. (doi:10.1074/jbc.M010043200)

Otsuka F, Yamamoto S, Erickson GF \& Shimasaki S 2001b Bone morphogenetic protein-15 inhibits follicle-stimulating hormone (FSH) action by suppressing FSH receptor expression. Journal of Biological Chemistry 276 11387-11392. (doi:10.1074/jbc.M010043200)

Pidoux G, Gerbaud P, Tsatsaris V, Marpeau O, Ferreira F, Meduri G, Guibourdenche J, Badet J, Evain-Brion D \& Frendo J-L 2007 Biochemical characterization and modulation of LH/CG-receptor during human trophoblast differentiation. Journal of Cellular Physiology 212 26-35. (doi:10.1002/jcp.20995)

Riccardi C \& Nicoletti I 2006 Analysis of apoptosis by propidium iodide staining and flow cytometry. Nature Protocols 1 1458-1461. (doi:10. 1038/nprot.2006.238) 
Ruoss C, Tadros A, O'Shea T, McFarlane J \& Almahbobi G 2009 Ovarian follicle development in Booroola sheep exhibiting impaired bone morphogenetic protein signalling pathway. Reproduction 138 689-696. (doi:10.1530/REP-09-0190)

Ryan K, Glister C, Lonergan P, Martin F, Knight P \& Evans A 2008 Functional significance of the signal transduction pathways Akt and Erk in ovarian follicles: in vitro and in vivo studies in cattle and sheep. Journal of Ovarian Research 1 2. (doi:10.1186/1757-2215-1-2)

Schmid I, Krall WJ, Uittenbogaart CH, Braun J \& Giorgi JV 1992 Dead cell discrimination with 7-amino-actinomycin D in combination with dual color immunofluorescence in single laser flow cytometry. Cytometry 13 204-208. (doi:10.1002/cyto.990130216)

Souza C, MacDougall C, Campbell B, McNeilly A \& Baird D 2001 The Booroola (FecB) phenotype is associated with a mutation in the bone morphogenetic receptor type 1 B (BMPR1B) gene. Journal of Endocrinology 169 R1-R6. (doi:10.1677/joe.0.169R001)

Stilley JA, Christensen DE, Dahlem KB, Guan R, Santillan DA, England SK, Al-Hendy A, Kirby PA \& Segaloff DL 2014 FSH receptor (FSHR) expression in human extragonadal reproductive tissues and the developing placenta, and the impact of its deletion on pregnancy in mice. Biology of Reproduction 91 74. (doi:10.1095/biolreprod.114.118562)

Takeda M, Otsuka F, Takahashi H, Inagaki K, Miyoshi T, Tsukamoto N, Makino H \& Lawson M 2012 Interaction between gonadotropinreleasing hormone and bone morphogenetic protein- 6 and -7 signaling in L $\beta$ T2 gonadotrope cells. Molecular and Cellular Endocrinology 348 147-154. (doi:10.1016/j.mce.2011.08.001)

Thomas FH, Ethier J-F, Shimasaki S \& Vanderhyden BC 2005 Folliclestimulating hormone regulates oocyte growth by modulation of expression of oocyte and granulosa cell factors. Endocrinology 146 941-949. (doi:10.1210/en.2004-0826)

Vermes I, Haanen C, Steffens-Nakken H \& Reutellingsperger C 1995 A novel assay for apoptosis. Flow cytometric detection of phosphatidylserine expression on early apoptotic cells using fluorescein labelled Annexin V. Journal of Immunological Methods 184 39-51. (doi:10. 1016/0022-1759(95)00072-I)
Westergaard L, Christensen IJ \& McNatty KP 1986 Steroid levels in ovarian follicular fluid related to follicle size and health status during the normal menstrual cycle in women. Human Reproduction 1 227-232.

Wilson T, Wu X-Y, Juengel JL, Ross IK, Lumsden JM, Lord EA, Dodds KG, Walling GA, McEwan JC, O'Connell AR et al. 2001 Highly prolific Booroola sheep have a mutation in the intracellular kinase domain of bone morphogenetic protein IB receptor (ALK-6) that is expressed in both oocytes and granulosa cells. Biology of Reproduction 64 1225-1235. (doi:10.1095/biolreprod64.4.1225)

Xia Y, O'Shea T, Murison R \& McFarlane JR 2003 Concentrations of progesterone, follistatin, and follicle-stimulating hormone in peripheral plasma across the estrous cycle and pregnancy in merino ewes that are homozygous or noncarriers of the Booroola gene. Biology of Reproduction 69 1079-1084. (doi:10.1095/biolreprod.102.005512)

Yuan W \& Giudice L 1997 Programmed cell death in human ovary is a function of follicle and corpus luteum status. Journal of Clinical Endocrinology and Metabolism 82 3148-3155.

Yung Y, Aviel-Ronen S, Maman E, Rubinstein N, Avivi C, Orvieto R \& Hourvitz A 2014 Localization of luteinizing hormone receptor protein in the human ovary. Molecular Human Reproduction 20 844-849. (doi:10.1093/molehr/gau041)

Zhu G, Cui Y, Wang Q, Kang Y, Lv Y, Wang J, Song Y \& Cao B 2013 Bone morphogenetic proteins (BMP) 2, 4, 6, and 7 affect ovarian follicular development through regulation of follicle-stimulating hormone receptor (FSHR) and luteinizing hormone (LHR) expression in goat granulosa cells. Journal of Cell Biology and Genetics 3 14-21. (doi:10.5897/ JCBG12.004)

Received 3 November 2014

First decision 15 December 2014

Revised manuscript received 26 April 2015

Accepted 5 May 2015 